\title{
Abbreviations and acronyms
}

$\begin{array}{ll}\text { ACT } & \text { Australian Capital Territory } \\ \text { AUD } & \text { Australian dollars } \\ \text { BIDs } & \text { Business Improvement Districts } \\ \text { CAD } & \text { Canadian dollars } \\ \text { CEDO } & \text { Commission of Economic Development Officials (US) } \\ \text { CHF } & \text { Swiss francs } \\ \text { CMEs } & \text { Coordinated Market Economies } \\ \text { DC } & \text { District of Columbia } \\ \text { EU } & \text { European Union } \\ \text { EUR } & \text { euros } \\ \text { FCC } & \text { Federal City Council (US) } \\ \text { FDA } & \text { Food and Drug Administration (US) } \\ \text { FDI } & \text { foreign direct investment } \\ \text { 5yEDS } & \text { Five Year Economic Development Strategy for the District } \\ & \text { of Columbia } \\ \text { GDP } & \text { Gross Domestic Product } \\ \text { GGBa } & \text { the Greater Geneva Berne Area } \\ \text { GWBoT } & \text { Greater Washington Board of Trade } \\ \text { GWI } & \text { Greater Washington Initiative } \\ \text { HAC } & \text { The Hague Academic Coalition } \\ \text { HSD } & \text { The Hague Security Delta } \\ \text { ICT } & \text { information and communications technology } \\ \text { IQ } & \text { InnovationQuarter (The Netherlands) } \\ \text { KIBS } & \text { knowledge-intensive business services } \\ \text { LMEs } & \text { Liberal Market Economies } \\ \text { MLG } & \text { Multilevel Governance } \\ \text { MRTH } & \text { Metropolitan Region of Rotterdam The Hague } \\ \text { MWCOG } & \text { Metropolitan Washington Council of Governments } \\ \text { NAFTA } & \text { North American Free Trade Agreement } \\ \text { NATO } & \text { North Atlantic Treaty Organization } \\ \text { NCC } & \text { National Capital Commission (Canada) } \\ \text { NCPC } & \text { National Capital Planning Commission (US) } \\ \text { NCR } & \text { National Capital Region (Canada) } \\ \text { NFIA } & \text { Netherlands Foreign Investment Agency } \\ & \\ & \end{array}$


NHI National Health Institute (US)

OCFO Office of the Chief Financial Officer (US)

OCRI Ottawa Centre for Research and Innovation

OECD Organisation for Economic Co-operation and

Development

OPWC Organization for the Prohibition of Chemical Weapons

PILT payment in lieu of taxes

R\&D research and development

RFIA Rotterdam Foreign Investment Agency (now Rotterdam Partners)

RIS Regional Innovation System

SASCs State-anchored secondary cities

SBB Schweizerische Bundesbahnen (Swiss Federal Railways)

SCCs Secondary Capital Cities

SGE Swiss Global Enterprise

TandemNSI Tandem National Security Innovations (US)

TNO The Netherlands Organization of Applied Scientific Research

TOP The Ottawa Partnership

UN United Nations

US United States

USD United States dollars

VoC Varieties of Capitalism theory

WHFIA West Holland Foreign Investment Agency (now The Hague Business Agency)

WSA Work and Social Assistance Act (The Netherlands) 